\title{
ERRATUM: EFFICACY OF ARBORJET VIPER MICROINJECTIONS IN THE MANAGEMENT OF HEMLOCK WOOLLY ADELGID (ADELGES TSUGAE)
}

\author{
By Joseph J. Doccola1, Ilangovan Ramasamy², Paulina Castillo, Christine Taylor ${ }^{4}$, \\ and Samantha Sifleet ${ }^{5}$
}

Editor's note: The authors have submitted this correction to their earlier paper, which was originally published in the November 2003 issue of the Journal of Arboriculture (29(6):327-330). This article clarifies the presentation of their statistical analyses.

\begin{abstract}
Hemlock woolly adelgid (Adelges tsugae Annand) is an introduced homopteran that infests native eastern hemlock (Tsuga canadensis Carriere). It results in reduced tree vitality and, when untreated, death. A state-of-the-art microinjection device employing an air-over-hydraulic system was used to deliver a therapeutic dosage of imidacloprid into the active xylem tissues of affected hemlocks. Bioassays were conducted microscopically to determine HWA mortality post-treatment. Injected trees had significantly $(P<0.05)$ lower HWA populations compared to untreated controls; mean mortality for injected trees was over twice that of noninjected trees. The Arborjet VIPER system shows promise as a management tool in the treatment of HWA.

Key Words. Adelges tsugae; Arborjet VIPER; Homoptera; imidacloprid; Tsuga spp.
\end{abstract}

Hemlock woolly adelgid (HWA) is an introduced piercingsucking insect that threatens forest and landscape hemlock species (Tsuga canadensis, T. caroliniana) throughout most of the tree's geographic range (USDA Forest Service 2002). The insect inserts its stylet into the xylem ray parenchyma cells of hemlock to extract carbohydrates (McClure 1991). The tree's vitality depends on these carbohydrates because this captured energy is crucial for growth, maintenance, reproduction, defense, and storage (Shigo 1991). McClure et al. (1996) have reported that dieback in hemlock may occur in 2 years, affecting the lower canopy first, and moves upward, even with HWA infestation distributed throughout the canopy.

For managing HWA infestations, three approaches are available: foliar sprays, soil injection, and trunk injection. A twice-yearly application of horticultural oil is the standard treatment for HWA, but efficacy depends on thorough foliar coverage of the contact insecticide and is subject to aerial drift. Soil injection of imidacloprid eliminates the problem of drift inherent in foliar applications, but leaching into the soil profile is a concern in sensitive sites. Microinjection is the most environmentally sensitive approach to pesticide application, but wounding and the possibility of subsequent girdling are of concern to the arborist. Arborjet VIPER microinjection was designed to address the concerns of environmental sensitivity and wounding of trees. It limits the number of injection sites set circumferentially around the trunk. The Arborjet VIPER system was selected for use in therapeutic treatments in this study (Figure 1).

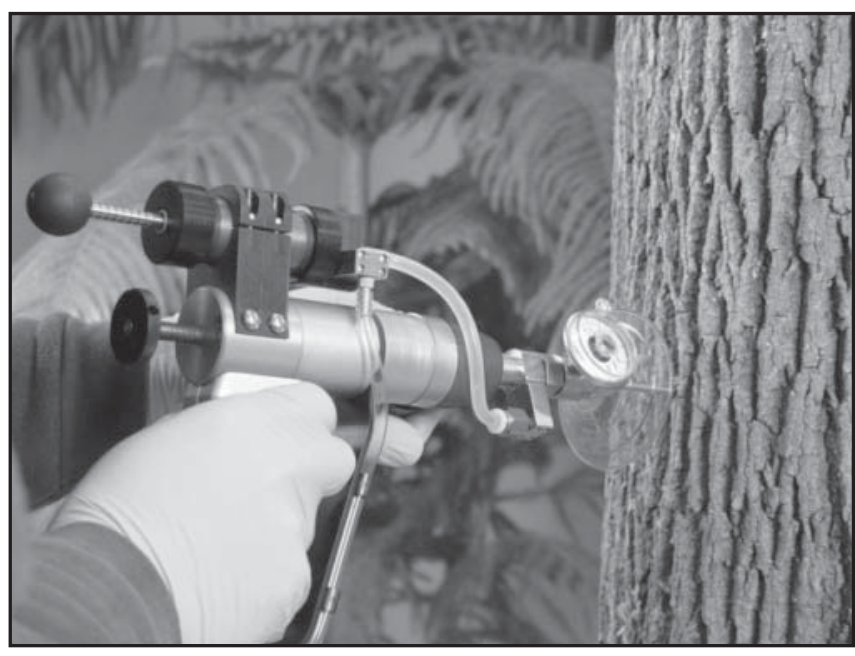

Figure 1. The Arborjet VIPER injection device, equipped with tree gauge to indicate injection pressure in the sapwood, and top mounted $10 \mathrm{~mL}$ Dose-Sizer ${ }^{\mathrm{TM}}$ to measure amount of formulation applied.

\section{METHODS \\ Tree Microinjection}

Twenty-four hemlocks were microinjected between 14 June and 1 August 2002 for HWA management. Trees were treated using 10\% formulation of 1-[(6-chloro-3-pyridinyl) methyl]-N-nitro-2-imidazolidinime (imidacloprid) by trunk injection into the active sapwood. Dosage was based on diameter at breast height (dbh, $135 \mathrm{~cm}$ [54 in.] from soil level, using a Lufkin $6 \mathrm{~m}$ [19.8 ft] diameter tape). Mean dosage applied per $2.5 \mathrm{~cm}$ (1 in.) dbh was $2.0 \mathrm{~mL}$ (0.06 oz). Mean dbh of microinjected hemlocks was $41.3 \mathrm{~cm}[16.5$ 
in.] and ranged from 18.8 to $85 \mathrm{~cm}$ ( 7.5 to 34 in.). All the microinjected trees were established urban forest trees.

Ports used in this study were cylindrical, barbed inserts with rubber septa that were set circumferentially into the trunk flare area. To place the ports, a portable $18.0 \mathrm{v}$ Ryobi drill (model\# HP1802M) with a $0.74 \mathrm{~cm}$ (0.3 in.) brad point bit was used to drill $2.5 \mathrm{~cm}$ (1 in.) into the active sapwood. The ports, $1 \mathrm{~cm}(0.4 \mathrm{in}$.) length x $0.9 \mathrm{~cm}$ (0.36 in.) diameter, tapering toward the proximal end, were configured with a "lip" to limit the depth of its setting at the current-year xylem. Set correctly, the port creates a small reservoir $(1.5 \times 0.75 \mathrm{~cm}$ [0.6 $0.3 \mathrm{in}]$.$) into which the solution is injected and from$ which it infuses into the tracheary elements of the tree. The probelike needle of the Arborjet device pierces the septum of the port and delivers up to $3.0 \mathrm{~mL}(0.09 \mathrm{oz})$ per trigger pull. Using the described port arrangement, $6.0 \mathrm{~mL}(0.18 \mathrm{oz})$ were deposited per port. For each tree, the total number of injection sites was determined using the formula dbh/3. Precise dosage delivery was aided by a pressure gauge at the tip of the injection device and $10 \mathrm{~mL}(0.3 \mathrm{oz})$ dose cartridge, or Dose-Sizer ${ }^{\mathrm{TM}}$. The tip gauge registered hydraulic pressures in the sapwood of Tsuga canadensis from 45 to 450 psi.

\section{Collecting Samples from Hemlock}

Twig samples were harvested in fall 2002 (between 22 October and 5 November) from 24 treated hemlocks randomly selected in the Winchester, Massachusetts, U.S. area. In addition, 24 nontreated trees were sampled at random during the same interval for HWA mortality assessment. Eight samples measuring 45 to $60 \mathrm{~cm}$ (18 to $24 \mathrm{in}$.) in length per tree were cut, bagged, labeled, refrigerated (at approximately $7.2^{\circ} \mathrm{C}$ $\left[45^{\circ} \mathrm{F}\right]$ and $60 \%$ relative humidity), and evaluated within 3 days. Samples were taken using a no. 180 ARS Long Reach pruner capable of $3 \mathrm{~m}$ ( $3.3 \mathrm{ft}$ ) extension, effectively reaching to $4.8 \mathrm{~m}$ (5.3 ft) into the canopy. Samples were taken from infested branches, typically from the lower to mid canopy.

\section{Evaluating Efficacy}

Microinjection treatment efficacy was evaluated on the basis of insect mortality. HWA mortality was based on a percentage of dead insects (adults and nymphs) as determined by microscopic inspection of $24045 \mathrm{~cm}$ (18 in.) samples infested with HWA. Insects were considered dead if they appeared desiccated, hard, discolored (darkened), and/or not responsive to stimuli (appendage, stylet, probe). The mortality percentage is the number of dead adelgids divided by total observed. HWA density is the number of live adelgids observed per linear centimeter of twig sample.

\section{RESULTS}

\section{Percentage of HWA Mortality}

In samples from treated trees, observed mean adelgid mortality was $85 \%$ for 104 samples, with a range of $58.2 \%$ to $100 \%$. Two-thirds of treated samples had $80 \%$ mortality or greater. For untreated samples, the mean mortality in 88 samples was $37.9 \%$, with a range of $6.9 \%$ to $81.7 \%$. Mortality of $80 \%$ or greater was observed in only $2.3 \%$ of the untreated samples (Figure 2).

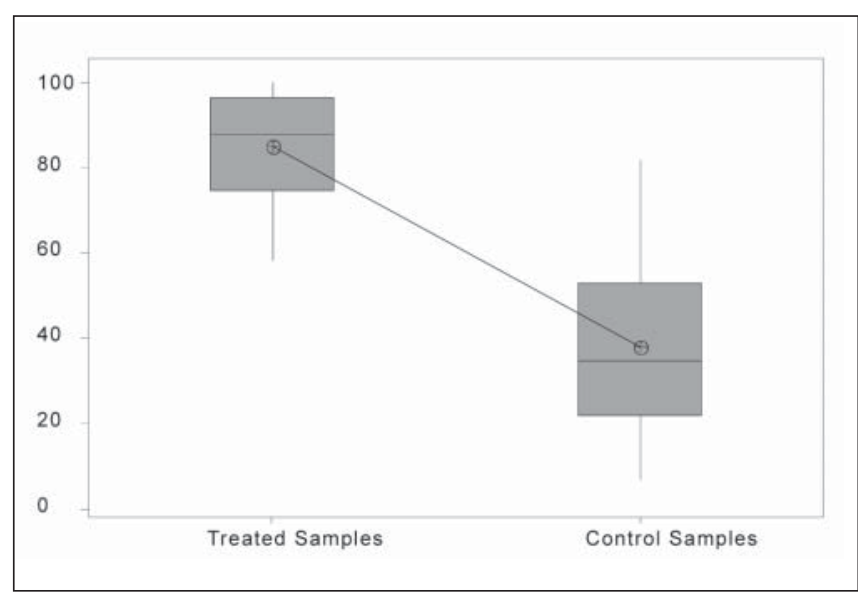

Figure 2. Boxplot of HWA mortality percentage in treated and control samples.

The data were analyzed using a Student's t-test to determine the difference between the mean percentage mortality of the treated and control samples. Minitab calculated a t-value of 19.50 and a p-value of 0.000 . We therefore have a $90 \%$ level of confidence that the true difference in the mean percentage of mortality of HWA of the treated and control populations ranges from $43.1 \%$ through $51.1 \%$.

\section{Live HWA Density}

Live HWA density was calculated for each sample by dividing the number of live adelgids by the sample length. Live HWA density is expressed in live HWA per linear centimeter.

The mean live HWA density for 104 treated samples was 0.45 live HWA per linear centimeter. The range for treated samples was 0 through 2.6 live HWA per linear centimeter. Of all treated samples, $87.5 \%$ had less than 1 live adelgid per linear centimeter (Figure 3, top).

The mean live HWA density for 88 control samples was 1.99 live adelgids per linear centimeter. The range for the control samples was 0.039 through 8.73 live HWA per linear centimeter. Only $31.8 \%$ of the control samples had less than 1 live HWA per linear centimeter (Figure 3, bottom).

A Student's t-test was used to determine the difference of the mean live HWA density on the treated and control samples. Minitab calculated a t-value of 9.18 and a p-value of 0.000 . (Note: There were two outlier values in the treated 


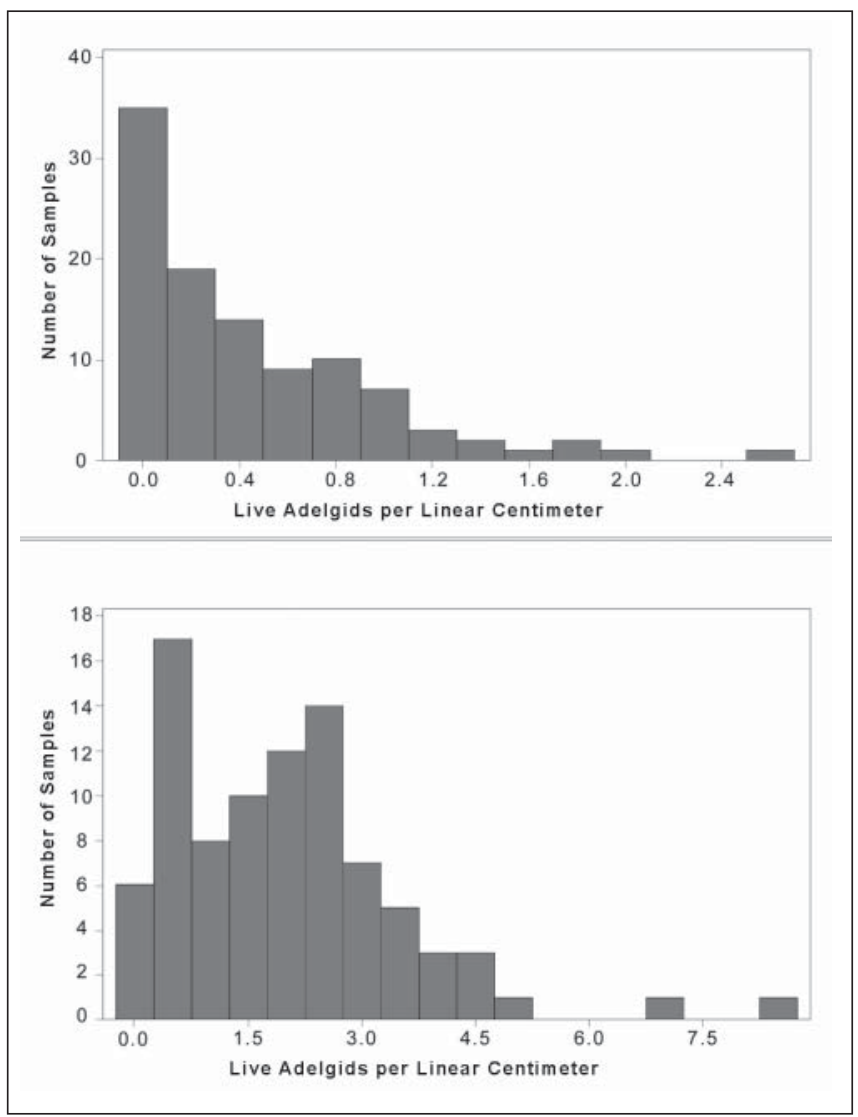

Figure 3. Histogram of treated samples (top) and control samples (bottom).

sample and four outlier values in the control sample. The Student's t-test was run without the outlier values, with the same results.) We therefore have a $90 \%$ level of confidence that the true difference between the mean live HWA density between the control and treatment populations ranges from 1.26 through 1.81 live HWA per linear centimeter.

\section{DISCUSSION}

In this study, imidacloprid-injected trees had significantly lower HWA populations than noninjected trees. The mean percentage of HWA mortality of injected hemlocks was $85 \%$ - over twice the mean mortality of nontreated hemlock trees. Tattar et al. (1998) also found the translocation of microinjected imidacloprid had similar effect on controlling the HWA.

It has been established that as HWA density increases, shoot extension decreases (McClure 1991; Doccola et al. 2002). We suspect that in protracted infestations with high HWA density ( $>2.0$ per linear centimeter), the reduction of vitality in hemlock branches also restricts translocation. In this study, $17 \%$ of the treated samples had HWA densities greater than 1 HWA per linear centimeter. Samples with high HWA density may have limited mortality due to reduced translocation of the systemic insecticide to those branches. Because movement of injected chemicals from injection site to target is dependent on the health of the transport tissues, it is critical to treat early while HWA populations are still low ( $<$ l HWA per linear centimeter).

Furthermore, our goal was to achieve therapeutic levels of insecticide that extend protection and lengthen the injection cycle to every 2 to 3 years. Residue studies are ongoing; however, we believe higher residues will result from applying insecticides at rates higher than applied in this study.

\section{CONCLUSIONS}

Therapeutic trunk injection treatments using the Arborjet VIPER system resulted in HWA mortality sufficient to maintain health in trees. Eighty-seven percent of all treated samples had less than 1 live adelgid per linear centimeter. The results of this study suggest that the Arborjet VIPER system is an effective management tool for trunk injection applications in the urban environment.

\section{LITERATURE CITED}

Doccola, J.J., P. Castillo, and C. Taylor. 2002. Hemlock health and hemlock woolly adelgid management in the urban forest. In Proceedings, Hemlock Woolly Adelgid in Eastern United States Symposium. Feb. 2002. Rutgers University and New Jersey Agricultural Experiment Station in cooperation with the USDA Forest Service.

McClure, M.S. 1991. density-dependent feedback and population cycles in Adelges tsugae (Homoptera: Adelgidae) on Tsuga canadensis. Environ. Entomol. 20:258-264.

McClure, M.S., S.M. Salom, and K.S. Shields. 1996. Hemlock Woolly Adelgid. Forest Health Technology Enterprise Team, USDA Forest Service, Morgantown, WV. 14 pp.

Shigo, A.L. 1991. Modern Arboriculture: A Systems Approach to the Care of Trees and their Associates. Shigo and Trees, Associates, Durham, NH.

Tattar, T.A., J.A. Dotson, M.S. Ruizzo, and V.B.Bruce. 1998. Translocation of imidacloprid in three tree species when trunk and soil injected. J. Arboric. 24:54-56.

USDA Forest Service. 2002. Hemlock Wooly Adelgid, Northeast Area-State \& Private Forestry. http:// na.fs.fed.us/fhp/hwa (accessed 6/7/05).

${ }^{1 *}$ Director of Research and Development

${ }^{2} P h . D .$, Chief Scientist

${ }^{3,4,5}$ Research Associate

Arborjet, Inc.

70 Cross Street

Winchester, MA 01890, U.S.

"Corresponding author 
Résumé. Le puceron lanigère de la pruche (Adelges tsugae Annand) est une espèce introduite d'homoptère qui a infesté les pruches du Canada indigènes (Tsuga canadensis Carriere). Ceci résulte en des arbres dont la vitalité est réduite ou mort lorsque les arbres ne sont pas traités. Selon les règles de l'art usuelles, un appareil d'injection avec un compresseur d'air hydraulique a été employé pour envoyer un dosage thérapeutique d'imidacloprid dans les couches actives de xylème de pruches affectées. Des bioessais ont été menés à l'échelle microscopique pour déterminer le taux de mortalité post-traitement du puceron lanigère. Les arbres injectés avaient des populations de pucerons lanigères significativement moindres $(P<0,05)$, et ce en comparaison avec les arbres non traités; le taux de mortalité moyen pour les arbres injectés était de plus du double par rapport aux arbres non injectés. Le système Arborjet VIPER s'est avéré prometteur comme outil de gestion pour le traitement des pucerons lanigères de la pruche.

Zusammenfassung. Die Douglasien-Wollschildlaus (Adelges tsugae Annand) ist eine eingeführte Homopteria, die einheimische Tsuga canadensis infiziert. Die Infektion führt zu reduzierter Vitalität und bei Nichtbehandlung zu Tod. Mittels eines hydraulischen Systems wurden Mikroinjektionen verwendet, um eine therapeutische Dosis von Imidacloprid in das aktive
Xylemgewebe der infizierten Tsugas zu applizieren. Es wurden mikroskopische Untersuchungen durchgeführt, um die Sterberate von den Insekten nach der Behandlung zu bestimmen. Injizierte Bäume hatten deutlich niedrigere Schildlauspopulationen als die ungehandelten Vergleichsbäume, die durchschnittliche Sterberate bei behandelten Bäumen betrug mehr als das Zweifache als bei unbehandelten. Das Arborjet VIPER System zeigte sich erfolgreich im Einsatz bei Wollschildlausbefall.

Resumen. El aldégido (Adelges tsugae Annand) (HWA) es un homóptero introducido que infesta los abetos nativos (Tsuga canadensis Carriere). Esto resulta en menor vitalidad y, cuando no son tratados, en la muerte de los árboles. Se usó un aparato hidráulico de microinyección y aire para aplicar una dosis terapéutica de imidacloprid dentro de los tejidos activos del xilema de los abetos afectados. Se llevaron a cabo bioensayos microscópicamente para determinar las poblaciones muertas de HWA post tratamiento. Los árboles inyectados tuvieron significativamente $(p<0.05)$ más bajas poblaciones de HWA comparados con los controles no tratados; la mortalidad media de HWA para árboles inyectados fue el doble que los no inyectados. El sistema VIPER Arboject se vio promisorio como una herramienta de manejo en los tratamientos de HWA. 